\title{
The Competitive Response of Panicum virgatum Cultivars to Non-Native Invasive Species
}

\author{
Lauren M. Schwartz ${ }^{1} \&$ David J. Gibson ${ }^{1}$ \\ ${ }^{1}$ Department of Plant Biology and Center for Ecology, Southern Illinois University Carbondale, Carbondale, \\ Illinois, USA \\ Correspondence: Lauren M. Schwartz, Department of Plant Biology and Center for Ecology, Southern Illinois \\ University Carbondale, Carbondale, IL 62901-6509, USA. Tel: 1-618-453-3231. E-mail: 1schwartz@siu.edu
}

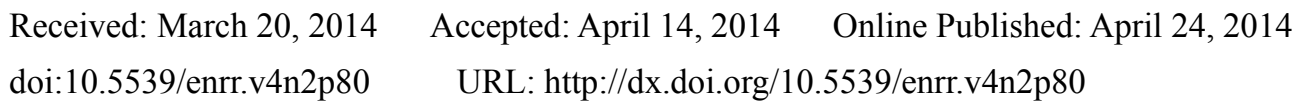

\begin{abstract}
It is important to use the most appropriate plant cultivar in restoration or biofuel trials especially when plantings are likely to be invaded by undesirable species. In this study, the competitive response of two lowland and three upland cultivars of the dominant $\mathrm{C}_{4}$ grass Panicum virgatum to three invasive species (Bromus inermis, Schedonorus phoenix, and Poa pratensis) was tested using a simple pair-wise greenhouse experiment. Response variables (height, number of leaves, tiller density, and biomass of $P$. virgatum) and resources (soil moisture and light intensity) were measured over a seven-month period. Performance of the different $P$. virgatum cultivars were differentially reduced by the three invasive species, especially the performance of the Kanlow (lowland) and Blackwell (upland) cultivars. Low soil moisture reduced the performance of $P$. virgatum in the presence of only one invasive (Bromus inermis) irrespective of cultivar source. Root, shoot, and total biomass depended on cultivar and did not show an interaction with invasive species identity. The results of this greenhouse study suggest that the $P$. virgatum cultivars differentially responded to the invasive species and that the cultivar used should be considered carefully in planning prairie restorations or biofuel trials in the context of likely invasive species.
\end{abstract}

Keywords: Panicum virgatum, invasive species, competition

\section{Introduction}

Non-native invasive species in North American tallgrass prairies have large ecological impacts (Nemec, Allen, Helzer, \& Wedin, 2013). These invasive species can quickly evolve in areas of disturbance through founder effects and hybridization by responding to selection pressures in the environment (Mealor \& Hild, 2006). Tallgrass prairies are vulnerable to invasive species because $90 \%$ of invaders are $C_{3}$ grasses (A. C. Cully, J. F. Cully, \& Hiebert, 2003). This is in contrast with the dominant prairie biomass, which is composed predominantly of $\mathrm{C}_{4}$ grasses. To help gain this advantage, invasive $\mathrm{C}_{3}$ species may use available resources before $\mathrm{C}_{4}$ species establish in assembling communities such as restoration or warm-season grass plantings (Culley et al., 2003). Invasive species in tallgrass prairies can alter soil chemistry, increase soil erosion, reduce forage and biofuel quality and wildlife populations, and fragment plant populations (Melor \& Hild, 2006). These species may spread with global climate change and in return this will cause a decrease in native species diversity (Maron \& Marler, 2007). Resource availability is also important to the habitat of the invasive species (Seabloom, Harpole, Reichman, \& Tilman, 2003). Communities within the tallgrass prairie with high species richness may be more resistant to invasive species than species-poor communities (Culley et al., 2003). Therefore, low-diversity restorations or plantings may be particularly susceptible to invasive species and an understanding of the competitive response of native $\mathrm{C}_{4}$ species to individual invasive species will help practitioners.

Switchgrass (Panicum virgatum $\mathrm{L}$.) is a perennial, warm season $\mathrm{C}_{4}$ grass occurring as many ecotypes that can dominate mesic tallgrass prairies in the Great Plains of North America (Parrish \& Fike, 2005). Ecologically, $P$. virgatum determines the structure and function of the North American tallgrass prairie. Panicum virgatum is photoperiod sensitive, and flowering is related to latitude, where northern ecotypes flower earlier than southern ecotypes (Lemus et al., 2002). Soil type has little effect on the development or morphology of $P$. virgatum (Parrish \& Fike, 2005; Porter, 1966). There is also considerable genotypic and phenotypic variation within the species. The variability within this species can be attributed to ecotypic adaptation across a large geographical 
and environmental range (Hartman, Nippert, Orozco, \& Springer, 2011). Panicum virgatum has considerable economic value as commercial cultivars have been developed from the native ecotypes and are widely planted for forage and hay, soil stabilization, wildlife habitat, and biofuel. Cultivars are generally divided into upland and lowland categories and within the last few decades, $P$. virgatum has been identified as an important biofuel crop (Vogel, 1996; Berdahl et al., 2005; Wang, Lebauer, \& Dietze, 2010). Understanding the response of P. virgatum cultivars to invasives is important in these settings.

Typically, upland cultivars of Panicum virgatum are associated with higher, mesic sites and lowland cultivars are associated with lower, wetter locations (Porter, 1966). Morphologically, upland cultivars are typically shorter, rhizomatous and have finer, thinner stems than lowland cultivars (Lemus et al., 2002). Upland cultivars tend to favor drier soils and are more susceptible to disease than lowland cultivars (Lemus et al., 2002). Lowland cultivars are vigorous, thick-stemmed, coarser, and can grow up to one meter taller than upland cultivars (Lemus et al., 2002). Compared with upland cultivars, lowland cultivars tend to grow better in wetter and denser soil (Porter, 1966). Upland cultivars grew best in more moderate moisture conditions (Porter, 1966). Upland and lowland cultivars vary in their nitrogen requirements. The lowland cultivars require less nitrogen than the upland cultivars (Porter, 1966). There are multiple ploidy levels among $P$. virgatum cultivars and ecotypes. Upland cultivars are hexaploids or octoploids and lowland cultivars are tetraploids (Parrish \& Fike, 2005; Porter, 1966).

The study aimed to determine whether native $P$. virgatum cultivars would grow and establish differently in the presence of non-native invasive species and to compare their ecological habitats. Specifically, the objective was to determine the competitive response of $P$. virgatum cultivars to non-native invasive species and to describe their responses in relation to non-native invasive species.

\section{Methods}

\subsection{Study Species}

The competitive response to invasive grasses of three upland cultivars (Blackwell, Cave in Rock and Trailblazer) and two lowland cultivars (Alamo and Kanlow) of Panicum virgatum were tested. The three upland cultivars are octoploid and the two lowland cultivars are tetraploid (Elbersen et al., 2001). Blackwell originated from Northern Oklahoma and is a disease resistant variety that produces vigorous stems and roots (Elbersen et al., 2001). Cave in Rock, originally from Southern Illinois, is palatable and disease resistant. This cultivar grows best in years of average rainfall and temperature and can reach an average of $3 \mathrm{~m}$ in height. Trailblazer is an upland cultivar from Nebraska (Elbersen et al., 2001) that is winter hardy, late maturing and has a high seed production (Elbersen et al., 2001). Alamo was developed in Texas and is a coarse-grained cultivar that matures late allowing for production into early fall (Parrish \& Fike, 2005). Kanlow, originally from Kansas, is suitable for growth in the southern 2/3rds of the United States and is especially well suited for poorly drained soils (Elbersen et al., 2001). Alamo and Kanlow produced more biomass than Blackwell, Cave in Rock, and Trailblazer in a 2000-2001 study by Lemus et al. (2002).

Three invasive species were tested, i.e., Poa pratensis L., Bromus inermis L., Schedonorus phoenix (Scop.) Holub (syn. S. arundinaceus (Schreb.) Dumort.), Festuca arundinaceae (Schreb.). These three species are all on a top ten list of prairie invaders (Culley et al., 2003) and are all cool season, $\mathrm{C}_{3}$ perennial, rhizomatous grasses (Kaufman \& Kaufman, 2007). Poa pratensis is native to Europe and northern Asia (Duble, 2000) and is used for erosion control, forage, recreation, wildlife cover, and as an ornamental (Huff, 2001; Shortell, Meyer, \& Bonos, 2009). Poa pratensis is found throughout North America except in the southwest (Duble, 2000). Bromus inermis is native to Europe and Asia and was introduced to North America in 1884 (Peeters, 2004; Roberts \& Kallenbackh, 2000). It is used for erosion control, wildlife cover, hay, silage and forage (Fink \& Wilson, 2011). Bromus inermis can be grown on a variety of soils and is found all over the United States and southern Canada (Kaufman \& Kaufman, 2007). This species is also drought resistant (Davis, Grime, \& Thompson, 2000). Schedonorus phoenix is native to Europe and North Africa and was introduced to North America in the late 1800s (Burns, Fisher, \& Pond, 2011). It is well adapted to humid, temperate areas (Burns et al., 2011) and can be found in all of the United States, except Florida, Georgia and Alabama, as well as Canada and Europe (Kaufman \& Kaufman, 2007; U.S. Department of Agriculture, 1948). Schedonorus phoenix is especially well adapted to rough ground and a variety of soil types (Gibson \& Newman, 2001). The preferred habitat is along open riverbanks, roadsides, edges of fields, prairies, and pastures (Kaufman \& Kaufman, 2007). Schedonorus phoenix is used primarily for forage, silage and hay (Gibson \& Newman, 2001).

\subsection{Experimental Design and Growth Conditions}

A greenhouse experiment was established using a simple pairwise competion design (Gibson et al., 1999) with a randomized complete block design with repeated measures. The treatment design was a fully factorial 
combination of five P. virgatum cultivars and a cultivar mixture (Alamo, Kanlow, Blackwell, Cave in Rock, Trailblazer, and a mixture of the cultivars), three invasive species (control [no invasives], Poa pratensis [local variety unknown, Belville Seed House, Inc.], Bromus inermis 'Lincoln', and Schedonorus phoenix 'KY 31'), and a moisture treatment (high and low), were established in three blocks. There were three replicates of each treatment combination for a total of $6 \times 4 \times 2 \times 3=144$ pots.

Plants were grown from seed in the Horticulture Research Center greenhouse (HRC) at Southern Illinois University Carbondale (SIUC) beginning in the summer of 2010. Seeds were planted in $15.2 \mathrm{~cm}$ diameter by $15.2 \mathrm{~cm}$ deep plastic pots filled with a 1:1 ratio of sand and silt-clay loam soil that was collected from the Southern Illinois University Carbondale Agronomy Center. The soil was sieved before use to remove rocks and other debris. Twenty seeds of a cultivar and twenty seeds of one of the invasive species were sown together in a grid system for a total of forty seeds per pot (seeding rates were adjusted as needed based on preliminary germination data). The pots were sterilized before use. After sowing, the pots were placed under a mister for two weeks. The pots were misted for 8-10 seconds every 12 minutes for 13 hours a day. Once seedlings had established, the pots were moved to a different wing of the same greenhouse. Upon emergence the twenty seedlings was thinned down to ten cultivar seedlings and ten invasive species seedlings per pot. Each of the five cultivars and a mixture of the five cultivars ( $n=6$ for cultivar treatment) were either planted as a monoculture (control) or with one of the three invasive species individually $(n=4$ for invasive species treatment). The cultivar mixture was planted in a grid so that each cultivar could be tracked. Control pots were sown with twenty seeds of a $P$. virgatum cultivar that were thinned down to ten seedlings following emergence with no invasive species seeded.

The experiment also tested the competiveness between the five cultivars under differing resource conditions: i.e., high moisture and low moisture. These conditions were chosen because the sites of origin of the P. virgatum cultivars vary in precipitation. The low moisture treatment was watered to field capacity twice every week and the high moisture treatment was watered to field capacity every five days using potable greenhouse water. Water treatments began August 3, 2010. Pots were fertilized twice (July 20, 2010 at $400 \mathrm{mg} \mathrm{g}^{-1} \mathrm{~N}$ and February 2, 2011 at $200 \mathrm{mg} \mathrm{g}^{-1} \mathrm{~N}$ ) with a 20-10-20 (NPK) Peters Water Soluble Fertilizer (JR Peters Inc., Allentown, Pennsylvania).

\subsection{Data Collection}

Number of vegetative tillers, number of leaves, and height of the $P$. virgatum cultivars was recorded on the plants in each pot. Measurements were recorded on three separate occasions (days 39, 166 and 213 of the experiment). The number of leaves and height of the $P$. virgatum cultivars were only analyzed for the first two dates of collection. Soil moisture was recorded for each pot eleven times with an $\mathrm{ECH}_{2} 0$ Decagon Soil Moisture meter (Decagon Devices, Inc., Pullman, Washington), which were collected on days 3, 19, 30, 43, 58, 70, 84, 98, 118,136 and 157 of the experiment. Light intensity at the soil surface was recorded using a LI-COR Light Meter (Model LI-250, LiCOR, Lincoln, Nebraska) eleven times (days 3, 19, 30, 43, 58, 70, 84, 98, 118, 136 and 157 of the experiment). Biomass of both the cultivars and of the non-native invasive species was measured at the end of the experiment after 213 days (collected March 4-5, 2011; days 214-215 of the experiment). The roots and shoots were harvested separately, dried for at least $48 \mathrm{hr}$ at $55^{\circ} \mathrm{C}$ and weighed.

The soil in the pots at the time of biomass harvest was tested for soil $\mathrm{pH}$ and conductivity on April 28-29, 2011. A 1:2 (15 grams of soil: $30 \mathrm{~mL}$ of deionized water) ratio of soil to deionized water was placed into $125 \mathrm{~mL}$ Pyrex Erlenmeyer flasks. The flasks were hand shaken and allowed to stand for 30 minutes. After 30 minutes, the flasks were covered with one square of Parafilm and placed on a New Brunswick Scientific Innova 2000 platform shaker for 30 minutes at 250 rpms (Robertson, Coleman, Bledsoe, \& Sollins, 1999). Once a slurry was attained, conductivity was tested with an EcoSense, EC 300 conductivity meter. Soil pH was tested on the same samples after conductivity was tested with a Fisher Scientific Accument, AP62 pH meter. The pH meter was calibrated before use with three Fisher Scientific buffer solutions ( $\mathrm{pH} 4.00, \mathrm{pH} 7.00$ and $\mathrm{pH} 10.00)$. In between each test, the conductivity or $\mathrm{pH}$ meter probe was dipped into deionized water and wiped with a Kimberly Clark Professional kimwipe. Samples were not allowed to settle.

\subsection{Data Analysis}

Data were analyzed using a repeated measures mixed model in SAS (PROC MIXED, SAS Institute, 2003) to determine if there were significant differences in the performance (mean tiller density, leaf number, plant height per pot) of $P$. virgatum, soil moisture and light intensity between cultivar (6 treatment levels), invasive species (4 treatment levels) and soil moisture ( 2 treatment levels) treatments or their interaction. The repeated measure was the number of days from the start of the experiment that a measurement was taken. The three groups in which the 
pots were placed on the greenhouse bench were included as random effects (blocks) in the model. Biomass, soil $\mathrm{pH}$ and soil electrical conductivity was analyzed using a three-way mixed model. Significance was assessed at $P$ $<0.05$. A post-hoc Tukey's test was used to determine significant differences among means.

\section{Results}

Vegetative tiller number per plant of $P$. virgatum cultivars was related to the interaction between cultivar and day (Table 1, Figure 1). After an initial period of growth, tiller number decreased in both the lowland cultivars and the upland cultivars from day 166 to day 213. The highest tiller number was found in Cave in Rock on day 39. The mixture of cultivars had the highest number of tillers per plant on day 213. There was a marginally significant interaction between invasive species and day (Figure 2). The number of tillers per plant of $P$. virgatum was lowest when planted with $B$. inermis on day 39 and 166; but by day 213 , differences in the number of tillers per plant of $P$. virgatum did not differ in response to the invasive species. On day 39, there were fewer tillers of $P$. virgatum associated with $B$. inermis than compared with in the monoculture controls, or with $S$. phoenix and with $P$. pratensis on day 166 . All $P$. virgatum plants had died in the pots planted with $B$. inermis by day 213 of the experiment. There were no data for reproductive tiller number because $P$. virgatum did not flower over the course of the experiment. There was a significant difference in root biomass, belowground biomass of $P$. virgatum cultivars, and the total belowground biomass only among P. virgatum cultivars. The highest belowground biomass of $P$. virgatum was in the cultivar mixture (Table 2, Figure 3). The highest aboveground biomass was found in Blackwell, Trailblazer, and the cultivar mixture (Figure 4). Cave in Rock had the lowest aboveground biomass out of the five cultivars.

Table 1. F statistics from mixed model analysis conducted on height, number of leaves, and tiller number of Panicum virgatum plants in response to the effects of $P$. virgatum cultivars (CV), invasive species (INV), and soil moisture (Moist) treatments over time (DAY). Subscripts represent the denominator of the degrees of freedom (DF)

\begin{tabular}{|c|c|c|c|c|c|}
\hline Effect & $\begin{array}{l}\text { Num. DF (Ht } \\
\text { and No. Lvs) }\end{array}$ & $\begin{array}{l}\text { Num. DF } \\
\text { (Tiller) }\end{array}$ & Height & No. of Leaves & $\begin{array}{l}\text { Tiller number } \\
\text { per plant }\end{array}$ \\
\hline Cultivar (CV) & 5 & 5 & $95.41_{83.5}{ }^{* * *}$ & $0.44_{83.2^{+}}$ & $26.79_{94}{ }^{* * *}$ \\
\hline Moisture (Moist) & 1 & 1 & $63.84_{83.5^{* * *}}$ & $1.14_{83.5^{+}}$ & $14.41_{94^{* *}}$ \\
\hline CV*Moist & 5 & 5 & $7.21_{83.6}^{* * *}$ & $0.32_{83.2^{+}}$ & $0.77_{94}^{+}$ \\
\hline Invasive (INV) & 3 & 3 & $1.56_{83.6^{+}}^{+}$ & $0.49_{83.5^{+}}$ & $3.99_{94}{ }^{*}$ \\
\hline CV*INV & 15 & 15 & $1.55_{83.5^{+}}$ & $1.01_{83.2^{+}}$ & $0.48_{94}^{+}$ \\
\hline Moist*INV & 3 & 3 & $1.99_{83.5^{+}}$ & $2.54_{83.5^{+}}$ & $0.75_{94}{ }^{+}$ \\
\hline CV*Moist*INV & 15 & 15 & $0.99_{83.4^{+}}$ & $1.17_{83.2^{+}}$ & $0.86_{94}^{+}$ \\
\hline DAY & 1 & 2 & $10.01_{79.2^{* *}}$ & $7.24_{79.6}{ }^{* *}$ & $506.24_{192}{ }^{* * *}$ \\
\hline$C V * D A Y$ & 5 & 10 & $16.76_{79}{ }^{* * *}$ & $0.98_{79.2^{+}}$ & $14.61_{192^{* * *}}$ \\
\hline Moist*DAY & 1 & 2 & $0.76_{79.2}^{+}$ & $7.99_{79.6}^{* *}$ & $8.27_{192^{* *}}$ \\
\hline CV*Moist*DAY & 5 & 10 & $6.46_{79}^{* * *}$ & $0.57_{79.2^{+}}^{+}$ & $1.35_{192}^{+}$ \\
\hline INV*DAY & 3 & 6 & $3.41_{79.2^{*}}$ & $0.23_{79.5^{+}}$ & $1.93_{192}{ }^{+}$ \\
\hline $\mathrm{CV} * \mathrm{INV} * \mathrm{DAY}$ & 15 & 30 & $2.16_{78.9}^{* *}$ & $0.85_{79}^{+}$ & $0.70_{192}{ }^{+}$ \\
\hline Moist*INV*DAY & 3 & 6 & $0.36_{79.2^{+}}$ & $0.63_{79.5^{+}}$ & $0.42_{192}{ }^{+}$ \\
\hline CV*Moist*INV*DAY & 15 & 30 & $0.88_{78.9^{+}}$ & $0.73_{79}^{+}$ & $0.79_{192}{ }^{+}$ \\
\hline
\end{tabular}

${ }^{*} \mathrm{P}<0.05,{ }^{* *} \mathrm{P}<0.01,{ }^{* * *} \mathrm{P}<0.001 ;$ Marginal significance: ${ }^{+} \mathrm{P}<0.1$. 


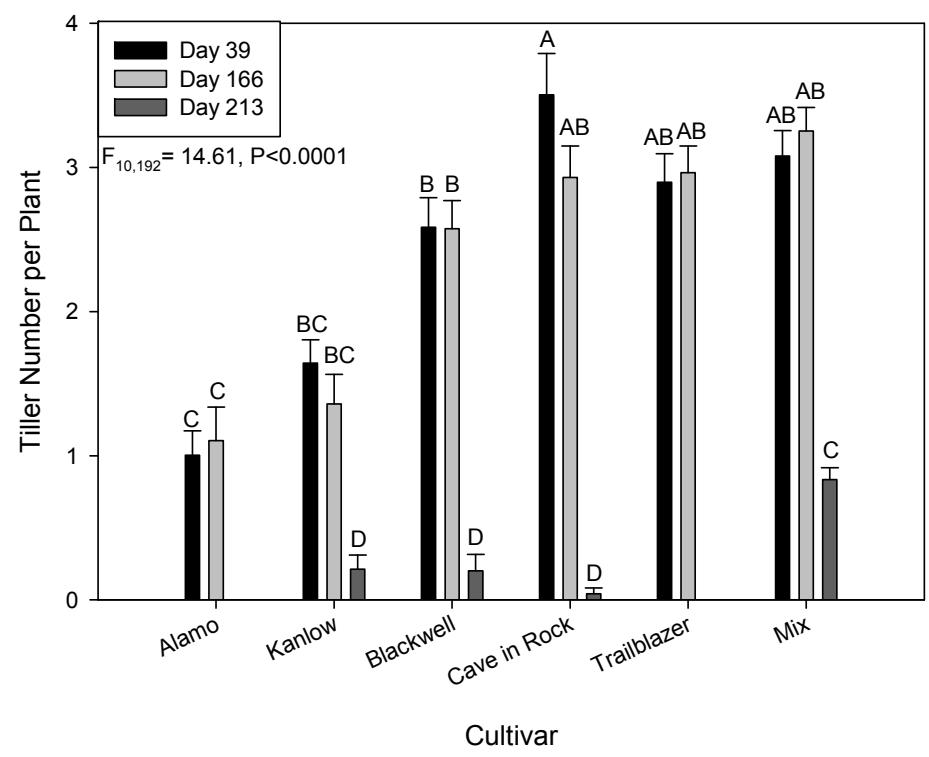

Figure 1. Mean $( \pm$ se) total tiller number per plant of $P$. virgatum cultivars and a mix of $P$. virgatum cultivars over three sampling dates. Mean values with the same letters are not significantly different at $\alpha=0.05$

Table 2. F statistics from mixed model analysis conducted on aboveground, belowground, and total aboveground biomass of Panicum virgatum plants in response to the effects of $P$. virgatum cultivars (CV), invasive species (INV), and soil moisture (Moist) treatments. Subscripts represent the denominator of the degrees of freedom (DF)

\begin{tabular}{lllll}
\hline Effect & Num. DF & $\begin{array}{l}\text { Aboveground } \\
\text { Biomass }\end{array}$ & $\begin{array}{l}\text { Belowground } \\
\text { Biomass }\end{array}$ & $\begin{array}{l}\text { Total Aboveground } \\
\text { Biomass }\end{array}$ \\
\hline Cultivar (CV) & 5 & $3.05_{94.1^{*}}{ }^{+}$ & $3.39_{94}{ }^{* *}$ & $2.65_{96}{ }^{*}$ \\
Moisture (Moist) & 1 & $0.25_{94.1}{ }^{+}$ & $0.11_{94}{ }^{+}$ & $0.04_{96}{ }^{+}$ \\
CV*Moist & 5 & $0.93_{94.1}{ }^{+}$ & $0.97_{94}{ }^{+}$ & $0.88_{96}{ }^{+}$ \\
Invasive (INV) & 3 & $0.14_{94.1}{ }^{+}$ & $1.34_{94}{ }^{+}$ & $16.18_{96}{ }^{* * *}$ \\
CV*INV & 15 & $1.24_{94.1^{+}}{ }^{+}$ & $1.33_{94}{ }^{+}$ & $1.04_{96}{ }^{+}$ \\
Moist*INV & 3 & $0.29_{94.1}{ }^{+}$ & $1.42_{94}{ }^{+}$ & $0.08_{96}{ }^{+}$ \\
CV*Moist ${ }^{*}$ INV & 15 & $1.19_{94.1}{ }^{+}$ & $1.06_{94}{ }^{+}$ & $1.46_{96}{ }^{+}$ \\
\hline
\end{tabular}

${ }^{*} \mathrm{P}<0.05,{ }^{*} \mathrm{P}<0.01,{ }^{* * *} \mathrm{P}<0.001$; Marginal significance: ${ }^{+} \mathrm{P}<0.1$. 


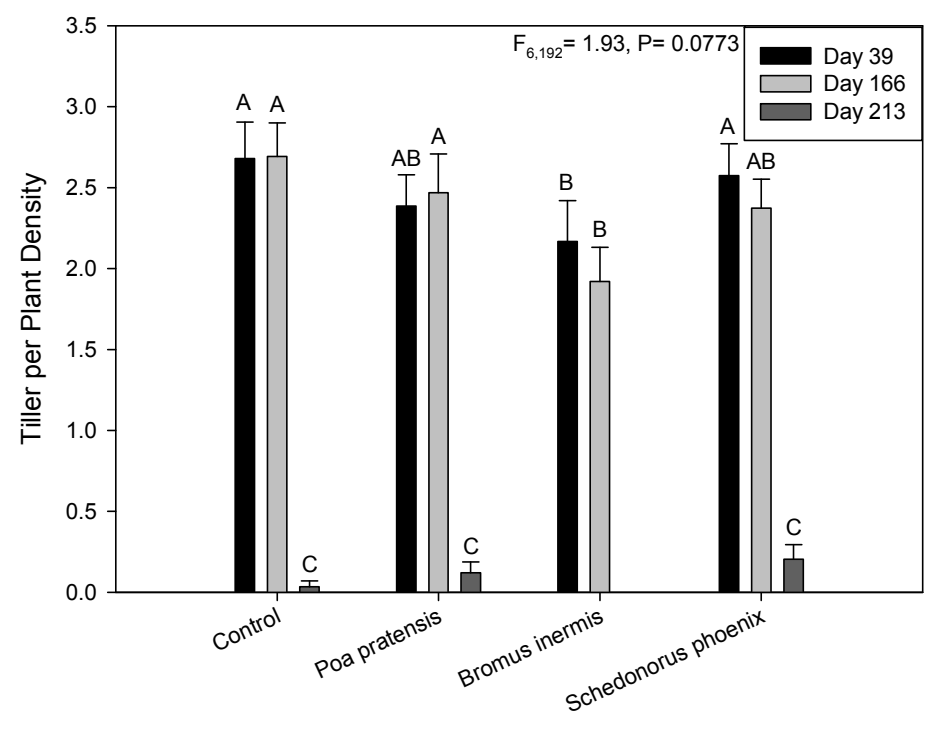

Invasive Species

Figure 2. Mean $( \pm \mathrm{se})$ total tiller number per plant of the P. virgatum cultivars in response to the three invasive species or no invasive species (control) over three sampling dates. Mean values with the same letters are not significantly different at $\alpha=0.05$

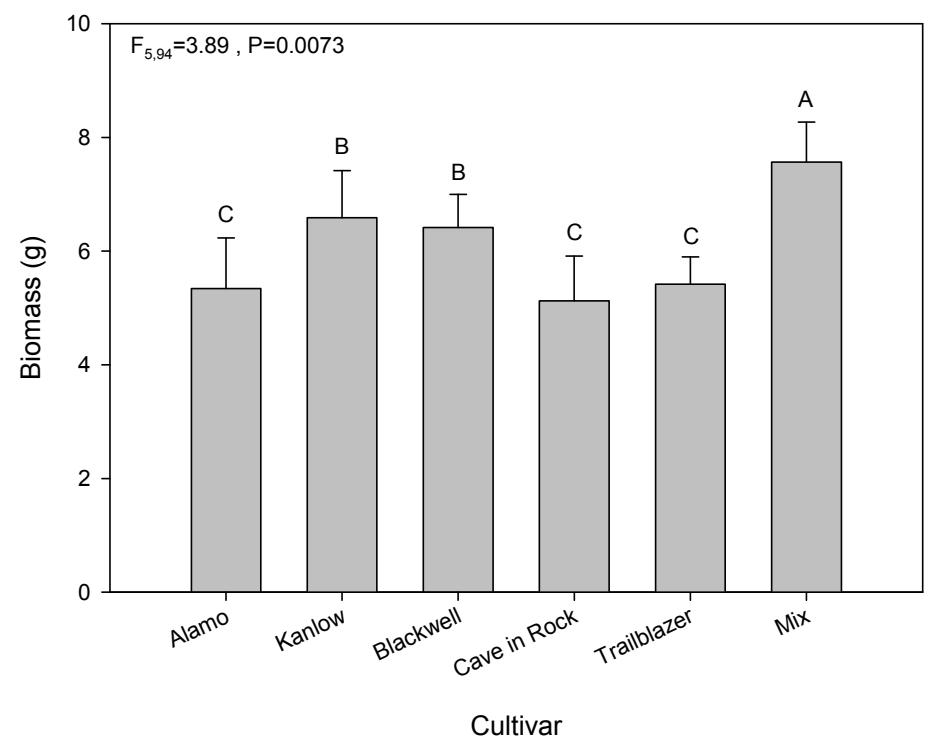

Figure 3. Mean ( \pm se) total belowground biomass of $P$. virgatum and invasive species in response to planted cultivar. Mean values with the same letters are not significantly different at $\alpha=0.05$ 


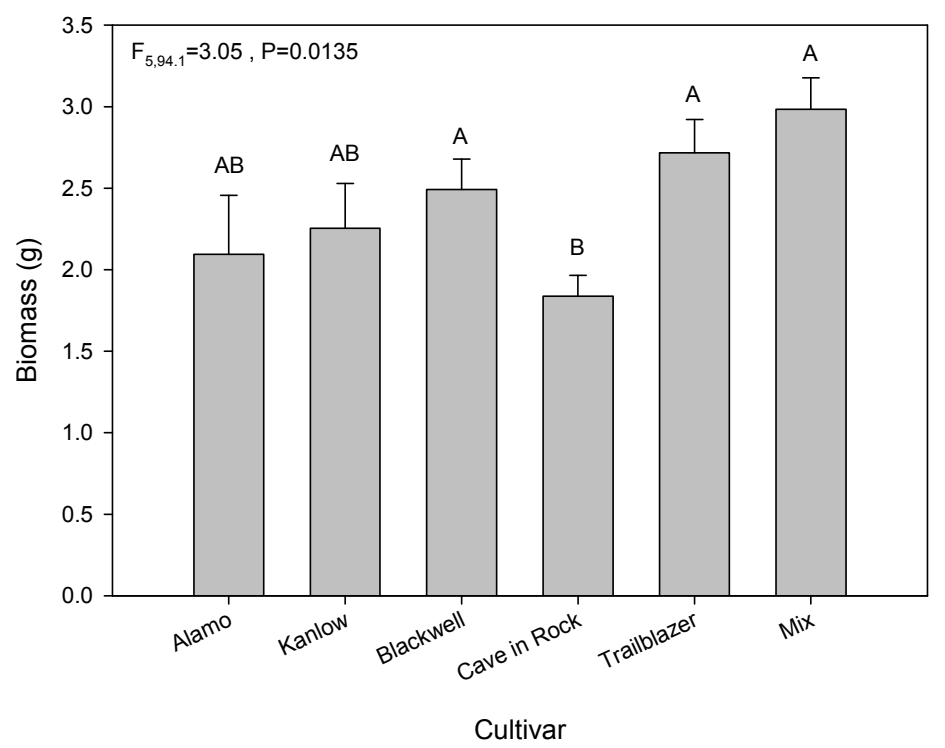

Figure 4. Mean ( $\pm \mathrm{se})$ aboveground biomass of $P$. virgatum cultivars. Mean values with the same letters are not significantly different at $\alpha=0.05$

There was a highly significant difference in height $(\mathrm{P}<0.0001)$ among cultivars, especially Kanlow, Cave in Rock, Trailblazer, and the cultivar mixture over days 39 and 166 (Table 1). There was also a three-way interaction between day, cultivar, and invasive species affecting the mean height of $P$. virgatum between cultivars and invasive species that showed two main patterns. Kanlow on day 39 was shorter than the upland cultivars in the presence of invasive species, but was taller with the presence of P. pratensis on day 166. Blackwell, however, showed the opposite pattern to Kanlow; on day 39, the cultivar grew taller with $S$. phoenix than with the other two invasive species, but by day 166 this difference was lost. Cave in Rock, on day 39, was tallest with $S$. phoenix and remained the same on day 166 . The cultivar mix showed similar results as Kanlow, i.e., there was a reduced height in the presence of an invasive species. Leaf number of $P$. pratensis and $S$. phoenix were individually affected by the moisture treatment (Table 1). Schendonorus phoenix showed a significant difference in performance among moisture treatments; whereas P. pratensis did not. The height of P. pratensis was not significantly different among $P$. virgatum cultivars; however, the height of $S$. phoenix was shorter in the presence of a cultivar compared with when grown in the cultivar mix.

There was a significant interaction between cultivar and soil moisture treatment affecting soil moisture (Figure 5). In both low and high moisture treatment levels, the soil in the pots with the lowland cultivars (Alamo and Kanlow) had low soil moisture levels; whereas, the soil in the pots with the upland cultivars (Blackwell, Cave in Rock, and Trailblazer) and the cultivar mixture had significantly higher levels of soil moisture. 


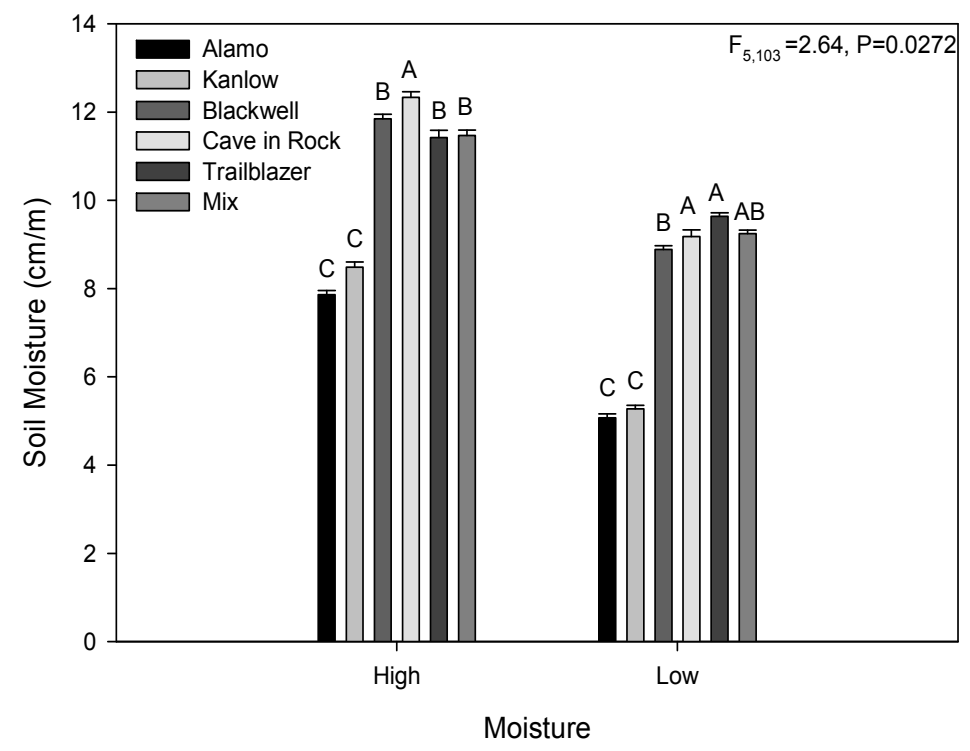

Figure 5. Mean ( $\pm \mathrm{se})$ soil moisture in response to cultivar under high and low moisture treatments. Mean values with the same letters are not significantly different at $\alpha=0.05$ within a soil moisture treatment

Soil electrical conductivity (EC) showed no interaction among treatments, but did show highly significant separate effects of both the $P$. virgatum cultivars and invasive species (Table 3 ). Among the P. virgatum cultivars, Trailblazer (upland) had the highest mean EC $(83.83 \pm 0.35 \mathrm{mS} / \mathrm{m}$ ); whereas, both lowland species (Alamo = $80.60 \pm 0.57 \mathrm{mS} / \mathrm{m}$ and Kanlow $=81.05 \pm 0.37 \mathrm{mS} / \mathrm{m}$ ) had the lowest mean EC. Schedonorus phoenix had the highest mean EC for the invasive species $(83.93 \pm 0.27 \mathrm{mS} / \mathrm{m})$; with $B$. inermis having the lowest mean EC $(82.25 \pm 0.31 \mathrm{mS} / \mathrm{m})$, but in neither case was EC under an invasive species significantly different to it in the control pots. Soil $\mathrm{pH}$ showed a highly significant interaction between $P$. virgatum cultivars and invasive species $(\mathrm{P}=0.0013$, Table 3$)$. Among the lowland cultivars, the controls had a lower mean $\mathrm{pH}(5.97 \pm 0.03)$ than the invasive species $(6.43 \pm 0.03)$. The soil in the pots with Poa pratensis had the highest mean $\mathrm{pH}$ for both lowland cultivars $(6.51 \pm 0.33)$. The upland cultivars and the cultivar mixture consistently had the highest mean soil $\mathrm{pH}$ when growing in the presence of S. phoenix $(6.89 \pm 0.17)$.

Table 3. F statistics from mixed model analysis conducted on soil electrical conductivity (EC) and soil $\mathrm{pH}$ of Panicum virgatum plants in response to P. virgatum cultivars (CV), invasive species (INV), and soil moisture (Moist) treatments. Subscripts represent the denominator of the degrees of freedom (DF)

\begin{tabular}{|c|c|c|c|}
\hline Effect & Num. DF & Soil EC & Soil pH \\
\hline Cultivar (CV) & 5 & $9.02_{94}^{* * *}$ & $8.03_{96}{ }^{* * *}$ \\
\hline Moisture (Moist) & 1 & $5.31_{94^{+}}$ & $0.36_{96}{ }^{+}$ \\
\hline CV*Moist & 5 & $1.12_{94}^{+}$ & $0.66_{96}^{+}$ \\
\hline Invasive (INV) & 3 & $16.39_{94}{ }^{* * *}$ & $11.99_{96}{ }^{* * *}$ \\
\hline $\mathrm{CV}^{*} \mathrm{INV}$ & 15 & $1.63_{94}^{+}$ & $2.78_{96}^{* *}$ \\
\hline Moist*INV & 3 & $0.93_{94}^{+}$ & $0.96_{96}{ }^{+}$ \\
\hline CV*Moist*INV & 15 & $1.50_{94}^{+}$ & $0.62_{96^{+}}$ \\
\hline
\end{tabular}

\section{Discussion}

Previous studies have suggested that competition among plants is relatively unimportant in unproductive, or stressful, environments because resource levels are low (Goldberg \& Novoplansky, 1997; Grime, 1979). 
Consequently, it has been suggested (Newman, 1973; Tilman, 1987) that unproductive environments are dominated by species that are poor competitors but are highly stress tolerant because they survive better than other species during periods of severe resource shortage. Therefore, it was predicted that cultivars from the least productive environments (i.e. upland cultivars) would minimize their competitive response at the expense of stress tolerance in the presence of neighboring non-native invasive species compared with lowland cultivars from more productive environments.

The greenhouse experiment showed that the height, number of leaves, and tiller density of the lowland cultivars were affected by the presence of the invasive species (Schwartz, 2011). The lowland cultivars had fewer tillers than the upland cultivars, in contrast to findings reported in a study by Porter (1966). However, lowland cultivars tend to grow more slowly than upland cultivars in the first year (Hartman et al., 2011) and grow better under the highest moisture conditions (Berdahl et al., 2005; Lemus et al., 2002). The response of P. virgatum and the measurements of environmental resources (light, soil moisture, soil $\mathrm{pH}$ and EC) indicated that the cultivar mixture was less affected by the invasive species than the cultivar monocultures were. The cultivar mixture appeared to be more adaptable and had more resources available than the lowland cultivars. The cultivar mixture had the highest available soil $\mathrm{pH}$ and EC, with the exception of the Cave in Rock cultivar, which had the highest mean soil moisture in the high moisture level treatment. The intraspecific interaction could be a factor because the cultivars have similar resource requirements (Mangla et al., 2011). Initially the cultivar mixture responded best to the invasive species (Wassmuth et al., 2009); however, the resources in the cultivar mixture became depleted in this study (Brown et al., 2008). The resource depletion could be due to the germination, emergence and initial root and shoot development, which may be very sensitive to competition for resources (Foster, 1999).

Total biomass and biomass of the individual plant parts showed no interactions between $P$. virgatum cultivar and the invasive species. This lack of relationship could be a real effect or be due to the length of time that the experiments were conducted (i.e. a Type II experimental error falsely interpreting a lack of an effect as a real effect) if the experiment ran too long for an interaction to be present. However, the lowland cultivars had higher aboveground biomass compared to the upland cultivars (consistent with Lemus et al., 2002). A limitation of interpreting these biomass measurements could have been that the plants may have become root-bound by the end of the experiment, which had run for 213 days. A greater investment in belowground biomass, compared to aboveground biomass, may reflect the importance of over wintering in perennial plants, and the survival through unproductive environments as dormant underground roots (Raven, Evert, \& Eichhorn, 1999). The performance measurements (i.e. plant height, number of vegetative tillers, and leaf number), however, help alleviate these limitations by assessing the temporal responses to competition exhibited by the P. virgatum plants.

Bennett et al. (2011) showed that invasive species strongly affects soil microbial communities, thus altering the native species around them. This effect of the soil microbial community could be an explanation for the response of the $P$. virgatum cultivars to the non-native invasive species. In this greenhouse experiment, $B$. inermis grew taller and had more leaves than the other two invasive species. An explanation for this could be that these plants did not become root bound. The upland cultivars had the highest soil moisture when grown with P. pratensis; whereas the lowland cultivars had the highest soil moisture when grown with $S$. phoenix. Competition is partially driven by the available resources in the community. Non-native invasive species have been shown to decline in abundance as resource levels decrease (Barney \& DiTomaso, 2010; Maron \& Marler, 2007). The amount of available resources and the fact that the invasive species grew faster and larger in this experiment could be a reason why they competed so well with the $P$. virgatum cultivars.

\section{Conclusions}

This study indicates that competition with non-native invasive species can affect the performance of cultivars of Panicum virgatum, a dominant prairie species, in terms of its response and resource allocation. Cultivars showed early signs of allocating their resources to growth and not to competition. However, once the cultivars were established resource allocation shifted towards competition. The non-native invasive species, especially $B$. inermis, differentially affected the growth of $P$. virgatum cultivars. There was a positive relationship between response variables and the resources showing that the upland and lowland cultivars respond differently to soil moisture level not just alone as expected, but in a competitive environment. There was little competitive advantage of the cultivar mixture when compared to the $P$. virgatum monocultures. Therefore, cultivar selection may act as a potential filter on community and ecosystem assembly if intraspecific variation in the dominant species affects how they are able to compete with interspecific neighbors (Gibson et al., 2012).

The implications for ecosystem restoration are particularly relevant for the tallgrass prairie due to the extreme loss and degradation this system has experienced (Samson \& Knopf, 1994). Only about 10-15\% of the original 
extent of the tallgrass prairie remains (Camill et al., 2004; Samson, Knopf, \& Ostlie, 2004), and in some areas such as Illinois less than $0.01 \%$ of the tallgrass prairie remains (Illinois Department of Energy and Natural Resources, 1994). Prairie restoration projects are imperative to restore this highly degraded ecosystem and their success may depend on factors such as cultivar source. Therefore, cultivar selection and knowledge of the dominant grasses should be considered as a potential filter in tallgrass prairie restorations and in warm-season grass plantings (e.g. for biofuels) in response to invasive species invasions.

\section{Acknowledgements}

The authors would like to thank Southern Illinois University and the Department of Plant Biology for support of this research. We would also like to thank the SIU COPE Fund for financial support.

\section{References}

Barney, J. N., \& DiTomaso, J. M. (2010). Plant biotechnology for sustainable production of energy and co-products. Berlin: Springer-Verlag.

Bennett, A. E., Thomsen, M., \& Strauss, S. Y. (2011). Multiple mechanisms enable invasive species to suppress native species. American Journal of Botany, 98, 1086-1094. http://dx.doi.org/10.3732/ajb.1000177

Berdahl, J. D., Frank, A. B., Krupinsky, J. M., Carr, P. M., Hanson, J. D., \& Johnson, H. A. (2005). Biomass yield, phenology, and survival of diverse switchgrass cultivars and experimental strains in western North Dakota. American Society of Agronomy, 97, 549-555. http://dx.doi.org/10.2134/agronj2005.0549

Brown, C. S., Anderson, V. J., \& Claassen, V. P. (2008). Restoration ecology and invasive plants in the semiarid west. Invasive Plant Science and Management, 1, 399-413. http://dx.doi.org/10.1614/IPSM-08-082.1

Burns, J. C., Fisher, D. S., \& Pond, K. R. (2011). Tall fescue forage mass and canopy characteristics on steer ingestive behavior and performance. Crop Science, 51, 1850-1864. http://dx.doi.org/10.2135/cropsci2010.10.0578

Camill, P., McKone, M., Sturges, S., Severud, W., Ellis, E., Limmer, J., ... Trout, A. (2004). Community and ecosystem level changes in a species rich tallgrass prairie restoration. Ecological Applications, 14, 1680-1694. http://dx.doi.org/10.1890/03-5273

Cully, A. C., Cully, J. F., \& Hiebert, R. D. (2003). Invasion of exotic plant species in tallgrass prairie fragments. Conservation Biology, 17, 990-998. http://dx.doi.org/10.1046/j.1523-1739.2003.02107.x

Davis, M. A., Grime, J. P., \& Thompson, K. (2000). Fluctuating resources in plant communities: a general theory of invasibility. Journal of Ecology, 88, 528-534. http://dx.doi.org/10.1046/j.1365-2745.2000.00473.x

Duble, R. L. (2000). Kentucky bluegrass. Texas Cooperative Extension. Retrieved from http://aggiehorticulture.tamu.edu/plantanswers/turf/publications/bluegrass.html

Elbersen, H. W., Christian, D. G., El Bassem, N., Bacher, W., Sauerbeck, G., Alexopoulou, E., ... van den Berg, D. (2001). Switchgrass (Panicum virgatum L.) as an alternative energy crop in Europe. Final Report Fair 5-CT97-3701. Retrieved from http://switchgrass.nl/pdf/Sw_FinalRep_full2.pdf\#page=34

Fink, K. A., \& Wilson, S. D. (2011). Bromus inermis invasion of a native grassland: diversity and resource reduction. Botany, 89, 157-164. http://dx.doi.org/10.1139/B11-004

Foster, B. L. (1999). Establishment, competition and the distribution of native grasses among Michigan old-fields. Journal of Ecology, 87, 476-489. http://dx.doi.org/10.1046/j.1365-2745.1999.00366.x

Gibson, D. J., Allstadt, A., Baer, S. G., \& Geisler, M. G. (2012). Effects of foundation species genetic diversity on subordinate species richness in an assembling community. Oikos, 121, 496-507. http://dx.doi.org/10.1111/j.1600-0706.2011.19447.x

Gibson, D. J., \& Newman, J. A. (2001). Festuca arundinaceaSchreber (F. elatior L. ssp. Arundinacea Schreber Hackel). Journal of Ecology, 89, 304-324. http://dx.doi.org/10.1046/j.1365-2745.2001.00561.x

Goldberg, D., \& Novoplansky, A. (1997). On the relative importance of competition in unproductive environments. Journal of Ecology, 85, 409-418.

Grime, J. P. (1979). Plant strategies and vegetation processes. Chichester: John Wiley \& Sons.

Hartman, J. C., Nippert, J. B., Orozco, R. A., \& Springer, C. J. (2011). Potential ecological impacts on Switchgrass (Panicum virgatum L.) biofuel cultivation in the central great plains, USA. Biomass and Bioenergy, 35, 3415-3421. http://dx.doi.org/10.1016/j.biombioe.2011.04.055 
Huff, D. R. (2001). Characterization of Kentucky bluegrass cultivars using RAPD markers. International Turfgrass Society, 9, 169-175.

Illinois Department of Energy and Natural Resources. (1994). The changing Illinois environment: critical trends. Illinois Department of Energy and Natural Resources, Springfield, IL.

Kaufman, S. R., \& Kaufman, W. (2007). Invasive Plants. Mechanicsburg, PA: Stackpole Books.

Lemus, R., Brummer, E., Moore, K., Molstad, N., Burras, C., \& Barker, M. (2002). Biomass yield and quality of 20 switchgrass populations in southern Iowa, USA. Biomass and Bioenergy, 23, 433-442. http://dx.doi.org/10.1016/S0961-9534(02)00073-9

Mangla, S., Sheley, R. L., James, J. J., \& Radosevich, S. R. (2011). Intra and interspecific competition among invasive and native species during early stages of plant growth. Plant Ecology, 212, 531-542. http://dx.doi.org/10.1007/s11258-011-9909-z

Maron, J., \& Marler, M. (2007). Native plant diversity resists invasion at both low and high resource levels. Ecology, 88, 2651-2661. http://dx.doi.org/10.1890/06-1993.1

Mealor, B., \& Hild, A. (2006). Potential selection in native grass populations by exotic invasion. Molecular Biology, 15, 2291-2300. http://dx.doi.org/10.1111/j.1365-294X.2006.02931.x

Nemec, K. T., Allen, C. R., Helzer, C. J., \& Wedin, D. A. (2013). Influence of richness and seedling density on invasion resistance in experimental tallgrass prairie restorations. Ecological Restoration, 31, 168-185. http://dx.doi.org/10.3368/er.31.2.168

Newman, E. I. (1973). Competition and diversity in herbaceous vegetation. Nature, 244, 310. http://dx.doi.org/10.1038/244310a0

Parrish, D. J., \& Fike, J. H. (2005). The biology and agronomy of switchgrassf or biofuels. Critical Reviews in Plant Sciences, 24, 423-459. http://dx.doi.org/10.1080/07352680500316433

Peeters, A. (2004). Wild and sown grasses. Rome, Italy: Blackwell Publishing.

Porter, C. (1966). An analysis of variation between upland and lowland switchgrass, Panicum virgatum L., in Central Oklahoma. Ecology, 47, 980-992. http://dx.doi.org/10.2307/1935646

Raven, P. H., Evert, R. F., \& Eichhorn, S. E. (1999). Biology of Plants (6th edition). W. H. Freeman and Company/Worth Publishers.

Robertson, G., Coleman, D., Bledsoe, C., \& Sollins, P. (1999). Standard soil methods for long-term ecological research. New York, New York: Oxford University Press, Inc.

SAS Institute, Inc. (2003). SAS 9.1, Cary, NC, USA.

Samson, F., \& Knopf, F. (1994). Prairie conservation in North America. BioScience, 44, 418-421. http://dx.doi.org/10.2307/1312365

Samson, F., Knopf, F., \& Ostlie, W. (2004). Great plains ecosystems: past, present, and future. Wildlife Society Bulletin, 32, 6-15. http://dx.doi.org/10.2193/0091-7648

Schwartz, L. M. (2011). The competitive response of Panicum virgatum cultivars to non-native species in Southern Illinois. (Master's Thesis, University of Southern Illinois University, Carbondale). Retrieved from http://opensiuc.lib.siu.edu/theses/765

Seabloom, E., Harpole, W., Reichman,O., \& Tilman, D. (2003). Invasion, competitive disturbance, and resource use by exotic and native California grassland species. Proceedings of the National Academy of Sciences, 100, 13384-13389. http://dx.doi.org/10.1073/pnas.1835728100

Shortell, R. R., Meyer, W. A., \& Bonos, S. A. (2009). Classification and inheritance of morphological and agronomic characteristics in Kentucky bluegrass (Poa pratensis L.). Hort Science, 44, 274-279.

Tilman, D. (1987). On the meaning of competition and the mechanisms of competitive superiority. Functional Ecology, 1, 304-315.

United States Department of Agriculture. (1948). Grass: the yearbook of agriculture. Washington, D.C.: Government Printing Office.

Vogel, K. P. (1996). Energy production from forages (or American agriculture - back to the future). Journal of Soil Water Conservation, 51, 429-434.

Wang, D., Lebauer, D., \& Dietze, M. (2010). A quantitative review comparing the yield of switchgrass in 
monocultures and mixtures in relation to climate and management factors. Global Change Biology Bioenergy, 2, 16-25. http://dx.doi.org/10.1111/j.1757-1707.2010.01035.x

Wassmuth, B. E., Stoll, P., Tscharntke, T., \& Thies, C. (2009). Spatial aggregation facilitates coexistence and diversity of wild plant species in field margins. Perspectives in Plant Ecological and Evolution Systems, 11, 127-135. http://dx.doi.org/10.1016/j.ppees.2009.02.001

\section{Copyrights}

Copyright for this article is retained by the author(s), with first publication rights granted to the journal.

This is an open-access article distributed under the terms and conditions of the Creative Commons Attribution license (http://creativecommons.org/licenses/by/3.0/). 